\title{
Obituaries
}

\section{Professor R. W. Scarff}

ROBERT W. SCARFF, emeritus professor of pathology in the University of London, died on January 19 at the age of 70 in the Middlesex Hospital, the hospital he had entered as a medical student half a century before. He had been born near Glasgow, but his Scottish parents had moved south soon after, and he had attended the City of London School before entering the Middlesex Hospital Medical School in 1919. As soon as he qualified he joined the staff of the Bland-Sutton Institute of Pathology where he remained until his retirement forty-one years later, having been director for the last seventeen of those years after the death of Professor James McIntosh.

His first published research work dealt with the experimental production of atheromatous lesions in rabbits on which he gave a paper at the Pathological Society when he joined in 1928. Afterwards came a series of papers on the histology of virus infections of the central nervous system written in collaboration with J. McIntosh and, in 1929 , the first of a series of papers dealing with the histological features of carcinoma of the breast. Although he continued his interest in experimental aspects of vascular discase he bocame increasingly concerned with tumour pathology, particularly mammary cancer and bone tumours, and with the effects of irradiation on tumour growth. He was an enthusiastic protagonist of the value of histological grading in the prognosis of careinoma of the breast. His early researches on this theme, painstakingly carried out in collaboration with surgical colleagues in the days before systematic follow-up records were available, bocamo widely quoted. The title of professor of morbid anatomy and histology was conferred on him in 1946, and two years later he succeeded MeIntosh as professor of pathology and director of the institute, also becoming at this time treasurer of the Pathological Society, an office ho held for seventeen years.

In 1935 he was appointed secretary of the Scientific Advisory Committee of the British Empire Cancer Campaign of which Lord Horder was then chairman, and he continued as such until 1954 when he became honorary secretary of the campaign. He was secretary-general of the 1958 International Cancer Congress held in London, the organization of which had oceupied an increasing proportion of his time during the preeding two years. Shortly after this highly successful occasion, attended by 2,800 delegates from sixty-seven nations, he was appointed CBE. He played an active part in the founding of the International Council of Societies of Pathology, and became its first secretary and treasurer in 1962, an office he was only on the point of relinquishing at the time of his death. One of the activities of this council is the distribution to all its thirty-nine member pathological societies of sets of histological slides prepared by the WHO International Reference Centres for tumours of various sites. Scarff was a member of the first of these groups, that for lung tumours, of which Professor L. Kreyberg in Oslo was the head, and he himself was head of the second of these centres, that for breast tumours established at the Bland-Sutton Institute in 1960. As secretary of the ICSP he attended meetings of all the many centres subsequently established, and became a familiar figure to tumour pathologists throughout the world.

After retiring from the chair of pathology at the BST, Scarff continued as consultant adviser in pathology to the Ministry of Health, as he had been since 1960, and took up a part-time research appointment at Mount Vernon Hospital, Northwood.

Robert Scarff was a bachelor whose main sources of enjoyment outside his work were golf, the Savage Club and the pleasure of entertaining his numerous friends, including many pathologists from other countries who never failed to call on him on their visits to London and who, like us, will sadly miss a warm hearted and generous friend.

\section{Dr D. R. S. Kirby}

BY the death of David Richmond Steven Kirby on November 11,1969 , at the age of 37 , we have lost an outstanding reproductive physiologist, a brilliant, enthusiastic and inventive research worker and a man whose friendship was as generous as his talent was great.

David Kirby was born in Buckinghamshire and went to school in Molton Mowbray. After serving two years in the Royal Air Force, he spent a year with a chemical firm and then went to King's College, Durham, where he read zoology. In 1957 he became a research student at the Department of Zoology, Oxford, where he remained for the rest of his life. He was elected to a Ford Foundation Research Fellowship in 1960, and in 1963 he became a senior research officer. Two years later he was appointed tutor and fellow at St Catherine's College, and in 1967 he took up a university lectureship.

Over a period of nine years he wrote more than forty scientific papers, most of them about the origin and nature of the delicate physiological relationship between the mammalian mother and her foetus. Eight still remain to be published. During his years as a research student ho developed the technique of growing mouse blastocysts in tissues outside the utorus. It enabled him to discriminate between the effects of foetal development and of the uterine response during the formation of the placenta. This important technique was subsequently adopted by many other workers. He carried out histological studies on the growth of the trophoblast, and drew attention to the role of the uterine decidua in limiting trophoblastic invasion during pregnancy. Later, he became interested in the idea of the foetus as a homograft, and studied the mechanisms that protect the placenta from immunological rejection by its maternal host. Histochemical and electron microscopic studies by Kirby and his col. leagues led to the hypothosis that a major factor in this protection is the "fibrinoid" layer of mucoprotein that separates the trophoblast from the decidua. Later work has suggested that some cancer cells may be protected from rejection in a similar way. Kirby was also keenly interested in the implications of his studies for the problems of organ transplantation.

He did not have a mind that ran in narrow channels. Few who met him came away without an increased enthusiasm for their own subject, as well as for his. This capacity for generating enthusiasm was one of his greatest qualities, and it was exemplified by the wide range of studies that he carried out in cooperation with others. They covered such diverse subjects as the control of sex ratio in man, the maintenance of histocompatibility poly. morphism, the mode of action of intrauterine contraceptive devices and the effects of electric current on the healing of fractured bone.

David Kirby had a short life, but in the scales of judg. ment its quality will weigh heavier than many that last longer. 